\title{
Ichthyofauna of Gibe Sheleko National Park and Some Morphometric Relationships of Fish of the Tributary Rivers, Southern Ethiopia
}

Sefi Mekonen ( $\nabla$ mekonen.sefi@gmail.com )

Debre Berhan University

Abera Hailu

Wolkite University

\section{Research Article}

Keywords: Conservation, Diversity, Fishery, Fish Fauna, Freshwater, Park, Species

Posted Date: February 10th, 2021

DOl: https://doi.org/10.21203/rs.3.rs-157750/v1

License: (c) (1) This work is licensed under a Creative Commons Attribution 4.0 International License.

Read Full License 
Ichthyofauna of Gibe Sheleko National Park and some morphometric relationships of fish of the tributary rivers, Southern Ethiopia

\title{
${ }^{1}$ Sefi Mekonen * and ${ }^{2}$ Abera Hailu
}

${ }^{* 1}$ Department of Biology, College of Natural and Computational Science, Debre Berhan University, Ethiopia. P.O. Box, 445

${ }^{2}$ Department of Wildlife and Ecotourism Management, Wolkite University, Ethiopia

*Email: mekonen.sefi@gmail.com, mekonen.sefi@yahoo.com

\begin{abstract}
This study was carried out along a tributary of Gibe Sheleko National Park to investigate the diversity, relative abundance and morphometric characteristics of fish. By using monofilament gill-nets, fish were collected, their species identified and their morphometric data measured. A total of 10 species were identified, dominated overall by Synodontis schall (28.52\%), followed by Labeobarbus nedgia (18.88\%) and Labeobarbus intermedius (14.06\%). According to the Index of Relative Importance (IRI), S. schall was also first (49.13\%), followed by L. intermedius (15.49\%). There were no significance differences in the IRI values of fish and relative abundance between the dry and wet season ( $p>0.05)$. Synodontis schall had the largest girth $(23.1 \mathrm{~cm})$, but Clarias gariepinus had the largest eye diameter $(8.4 \mathrm{~mm})$ and body weight $(1713.4 \mathrm{~g})$. Heterobranchus longifilis was first in total fork and standard length $(64.7 \mathrm{~cm}, 64.7 \mathrm{~cm}$ and $59.8 \mathrm{~cm}$, respectively). However, the paired t test of the total body length was not significantly different from the fork length $(P>0.05)$, but not showing statistical differences from standard length, weight and girth $(P<0.05)$. Gibe River had a higher number of species (N) than Wabe River in both seasons. The Shannon Diversity Index $\left(H^{\prime}\right)$ in Gibe River was also higher (2.09) than Wabe (1.84) during the dry season, but lowest in the wet season (1.52 and 1.57, respectively). Furthermore, both $(N)$ and $\left(H^{\prime}\right)$ were not statistically different between tributaries and seasons $(p>0.05)$. Generally, differences in sampling habitats and fishing effort might have contributed to discovered variants findings. Fishery development should be implemented in the Park to use the fish resource sustainably.
\end{abstract}

Keywords: Conservation, Diversity, Fishery, Fish Fauna, Freshwater, Park, Species 


\section{INTRODUCTION}

Ethiopia is the water-tower of East Africa and endowed with several water bodies that contain a high diversity of aquatic fauna including fishes (Golubtsov and Mina 2003, Golubtsov and Darkov 2008). Ethiopia has a rich diversity of fish fauna in its lakes, rivers and reservoirs, although they are poorly known (Awoke 2015). Results of various studies indicate that the number of species could increase to over 200 (Awoke 2015, Awoke et al. 2015) and about 38 species and two sub-species are endemic to Ethiopia (Getahun 2007).

Although Ethiopia has a high production potential and diversity of fish fauna, during the last few decades, the fish biodiversity of the country has been declining rapidly due to different factors such as anthropogenic (like overfishing, urbanisation, damming, abstraction of waters for irrigation and power generation and pollution), lack of stakeholders' follow-up and governmental support and climate change (Tesfaye and Wolff 2014, Temesgen and Getahun 2016). These factors have subjected the natural water bodies in general and rivers in particular to severe stress with devastating effects on fish diversity (Golubtsov and Darkov 2008, Temesgen and Getahun 2016).

The knowledge of Ethiopian fish fauna diversity is far from complete (Golubtsov and Mina 2003, Kebede et al. 2017). Notable fishery investigations have been carried out only in a few of the numerous freshwater bodies (Temesgen and Getahun 2016), especially in the rivers that are not exhaustively explored (Getahun 2007). Limited works have been carried out regarding an estimation of the potential of the fish diversity profile of Ethiopian rivers, which are supposed to be economically important, including for a large number of small or medium rivers, such as the ones explored in this study location Gibe River (Golubtsov and Mina 2003, Awoke 2015, Tesfaye and Wolff 2014). Before our study, for the present study area of Gibe Sheleko National Park (GSNP), the tributaries were still virgin, because we had not found any literature resources and documents from the Park office regarding fish fauna. It is believed that this study was the first investigation of the Ichthyofauna diversity, including some morphometric measurement of fish in GSNP. Therefore, the main aim of this work was to address the present fish species of GSNP.

Descriptions of species diversity and abundance are important to obtain information on the quality and quantity of the available habitats (Begon et al. 1990, Gebremariam et al. 2002, Tesfaye and Wolff 2014). Fish have an essential role as an indicator of ecological integrity of running waters. Under this concept, there is an increasing emphasis on gathering biological data to serve a broad-spectrum of environment objects and plans, such as the

protection of endangered and threatened species and effective management and conservation of fish and fisheries have not been given much consideration in the management of fish fauna of GSNP. Gebe Sheleko National Park has not been given due attention regarding fish and fisheries. Therefore, the absence of information about the Park riverine fisheries triggered the necessity to conduct this study. The study on morphometric characters in fish is important because they can be used for taxonomic resolution and are able to spot differences between fish population growth parameters (Nagelkerke 1997). Therefore, this study was carried out to identify fish diversity, determine the relative abundance of fish species and to examine some morphometric measurements of the dominant fish of the GSNP to improve the Park and riverine 
fisheries management. The study provides preliminary information on the overall ecological character of the GSNP riverine ecosystems.

\section{MATERIALS AND METHODS}

\section{Study Area}

The study was conducted in Gibe Sheleko National Park, located in the Gurage Zone of Southern Ethiopia. It is $170 \mathrm{~km}$ south west of Addis Ababa. It is geographically located from $05^{\circ} 25^{\prime} \mathrm{N}$ to $06^{\circ} 15^{\prime} \mathrm{N}$ and $35^{\circ} 24^{\prime} \mathrm{E}$ (Fig. 1). The altitude of the area ranges from 1050 to $1835 \mathrm{~m}$ above sea levels. The park covers $248 \mathrm{~km}^{2}$ bounded by three Districts namely Cheha, Abeshigie and Enemorenaener. It characterised by a heterogeneous landscape, flora, fauna and habitat types and it is dissected by deep gorges of the Gibe, Deriee and Wabe Rivers. Gibe Sheleko National Park has viable populations of mammalian species and viable groups of fauna species to diversified flora and also involves varieties of bird species, reptiles and amphibians, as well as insects also being found (Amare 2015, Tilahun et al. 2017).

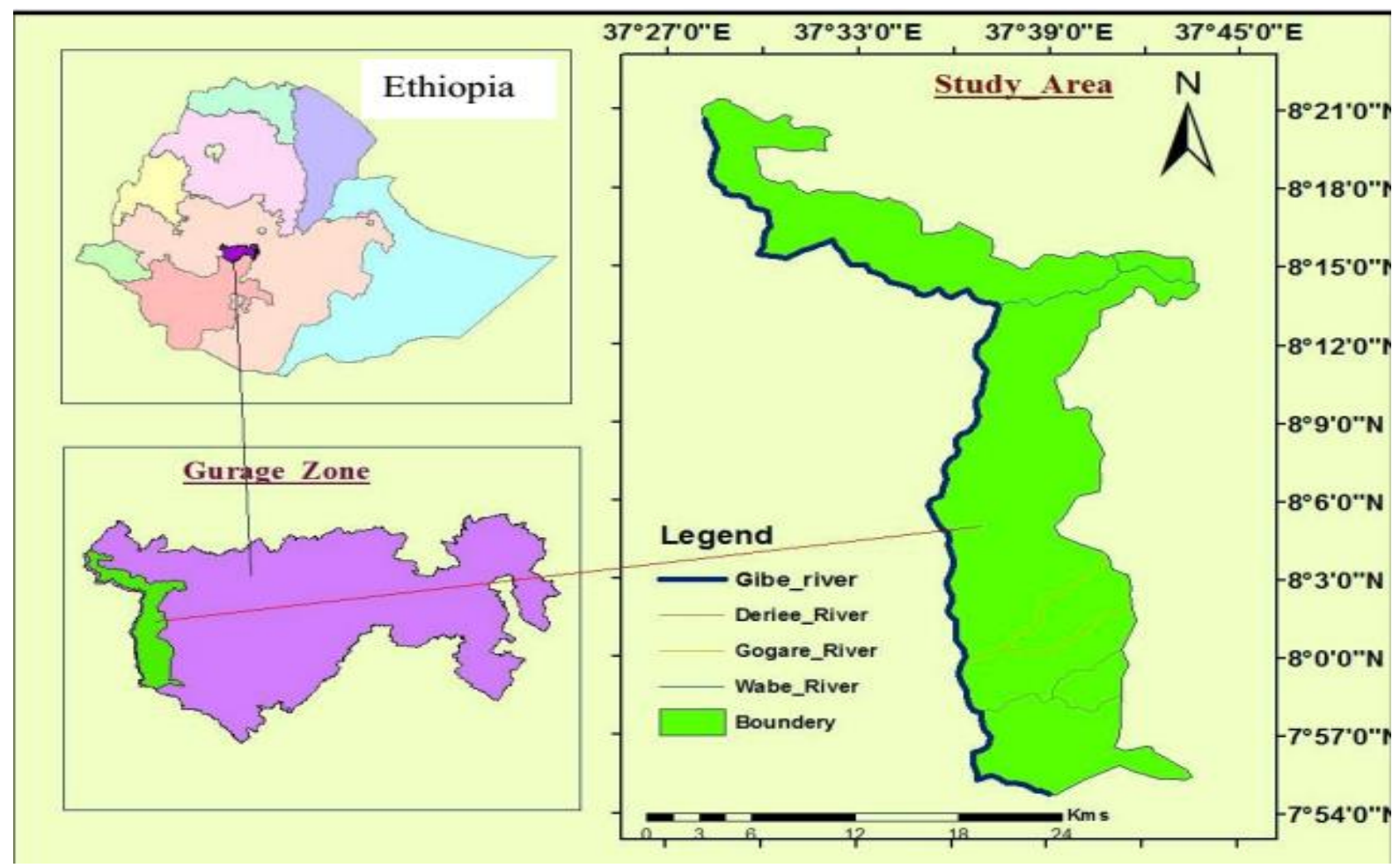

Figure 1. Map of Gibe Sheleko National Park (Source: Belete et al., 2017)

Site selection and field sampling

Based on information from local fishermen and a previous survey, we selected a total of eight sampling sites along the Gibe and Wabe Rivers (Table 1). Sampling sites were selected by 
considering the nature and velocity of the rivers, accessibility, substrate type and human interference in the river sections. The coordinates of the sampling sites were determined using GPS. Data were collected both in a dry season (January to March) and a wet season (April 16 to June) in 2019.

Table 1. Sampling sites with their codes, GPS readings and habitat type in Gibe and Wabe tributaries.

\begin{tabular}{|c|c|c|c|c|}
\hline Tributary & Fishing site & Altitude(m) & Habitat & Coordinate (GPS) \\
\hline \multirow{5}{*}{ Gibe River } & G1 & 1067 & Rocky and sandy & $08^{0} 13^{\prime} 91^{\prime \prime} \mathrm{N}, 037^{0} 34^{\prime} 41^{\prime \prime} \mathrm{E}$ \\
\hline & $\mathrm{G} 2$ & 1079 & Rocky and sandy & $08^{0} 13^{\prime} 99^{\prime \prime} \mathrm{N}, 037^{0} 34^{\prime} 30^{\prime \prime} \mathrm{E}$ \\
\hline & G3 & 1082 & Rocky and sandy & $08^{0} 13^{\prime} 81^{\prime \prime} \mathrm{N}^{\prime} 037^{0} 34^{\prime} 85^{\prime \prime} \mathrm{E}$ \\
\hline & G4 & 1086 & Rocky and sandy & $08^{0} 13^{\prime} 86^{\prime \prime} \mathrm{N}, 037^{0} 34^{\prime} 64^{\prime \prime} \mathrm{E}$ \\
\hline & G5 & 1084 & Rocky and sandy & $08^{0} 13^{\prime} 93^{\prime \prime} \mathrm{N}^{\prime} 037^{0} 34^{\prime} 44^{\prime \prime} \mathrm{E}$ \\
\hline Wabe & W1 & 1673 & Turbid muddy and rock gravel & $08^{0} 14^{\prime} 85 \mathrm{~N}, 037^{0} 45^{\prime} 41^{\prime \prime} \mathrm{E}$ \\
\hline \multirow[t]{2}{*}{ River } & $\mathrm{W} 2$ & 1669 & Turbid muddy and rock gravel & $08^{0} 14^{\prime} 78^{\prime \prime} \mathrm{N}, 037^{0} 45^{\prime} 39^{\prime \prime} \mathrm{E}$ \\
\hline & W3 & 1647 & Turbid muddy and rock gravel & $08^{0} 14^{\prime} 65^{\prime \prime} \mathrm{N}, 037^{0} 45^{\prime} 30^{\prime \prime} \mathrm{E}$ \\
\hline
\end{tabular}

Fish sampling and identification

On a monthly basis (January to June 2019), fish were collected using monofilament gill-nets which had mesh sizes of $5 \mathrm{~mm}$ to $55 \mathrm{~mm}$, a panel length of $25 \mathrm{~m}$ and depth of $1.5 \mathrm{~m}$. Hooks and locally-available traps were also used during fish sampling. Some specimens were also obtained from fishermen. Immediately after capturing the fish, morphometric measurements were recorded and all specimens were preserved in plastic jars containing 4\% formalin and labelled with all necessary information of fishes. Once back in the laboratory, the preserved specimens were soaked in tap water for 5 days to wash the formalin away and then transferred to $75 \%$ ethanol for conservation and identification. All specimens were identified to species level using taxonomic keys.

Morphometric measurements

Total length, fork length, standard length, girth, weight, eye diameter and the distance between eyes of fish specimens were measured using digital calipers, ruler and digital balance. Total Length (TL) was measured from the tip of the snout to the tip of the caudal fin, i.e. the greatest distance between the most 
anterior projecting parts of the head and the posterior most tip of the caudal fin. Standard Length (SL) was measured from the tip of the snout to the base of the caudal fin. It was a straight distance from the anterior most part of the head to the end of the vertebral column/caudal peduncle. Fork length (FL) was measured from the tip of the snout to the end of the middle caudal fin rays. Width (WD) was girth of body. Eye Diameter (ED) was distance from the anterior to the posterior rims of the eye in the longitudinal axis. Distance between Eyes (DBE) was distance between both eyes. Weight (W) was body total weight.

\section{Species diversity and relative abundance}

Estimation of relative abundance of fish was made by the contribution of the catch in each overnight fishing sample. The Index of Relative Importance (IRI) and Shannon Diversity Index ( $\left.\mathrm{H}^{\prime}\right)$ were used to evaluate relative abundance and diversity of fish, respectively. The IRI is a measure of relative abundance or commonness of the species, based on number and weight of individuals in catches, as well as their frequency of occurrence. IRI gives a better representation of the ecologically-important species rather than the weight, number or frequency alone (Sanyanga 1996).

$\%$ IRI $=\frac{(\% W i+\% N i) x \% F i}{\sum_{J-1}^{Z-1}(\% W j+\% N j) x \% F j} X 100$ Where, $\% \mathrm{Wi}$ and $\% \mathrm{Ni}$ are percentages weight and number of each species of total catch, respectively. $\% \mathrm{Fi}$ is a percentage frequency occurrence of each species in total number of settings. $\% \mathrm{Wj}$ and $\mathrm{Nj}$ are percentage weight and number of total species in total catch. Fj is percentage frequency of occurrence of total species in total number of settings. 
The Shannon Diversity Index $\left(\mathrm{H}^{\prime}\right): \mathrm{H}^{\prime}$ is a measure of species weighted by the relative abundance (Begon et al. 1990). $\mathrm{H}^{\prime}$ is calculated as follows: $\mathrm{H}^{\prime}=\sum \mathrm{pi} \ln \mathrm{pi}$; where, pi - the proportion of individuals in the ith species. The Shannon Index is used to indicate diversity of fishes at different sampling sites. A high value indicates high species diversity.

\section{Data Analysis}

Descriptive statistics were used to analyse the mean value of the biomass weight during wet and dry seasons and also the mean, range and standard error of the species length frequency. The significant difference of species relative abundance during wet and dry season was analysed using the t-test and Chi-square test. One-way ANOVA was used to determine the significant difference of species diversity between sites (SPSS, v.21).

\section{RESULTS}

\section{Fish Species Composition}

During this extensive study, a total of ten species referable to four orders and seven families were identified from Gibe and Wabe Rivers of GSNP in dry and wet seasons (Tables 2, 4). Cyprinidae was the predominant family representing three species, contributing $30 \%$ of the fish diversity in the Park, followed by Clariidae with two species (20\% of fish of study area). The freshwater fish fauna in the studied rivers contained a mixture of Nilo Sudanic: Mormyrus kannume Forsskål, 1775, Bagrus docmak (Forsskål, 1775) and Labeo forskalii (Rüppell, 1835); and highland East African forms: Labeobarbus intermedius (Rüppell, 1835), Labeobarbus nedgia (Rüppell, 1835), Clarias gariepinus (Burchell, 1822) and Oreochromis niloticus (Linnaeus, 1758).

In the studied rivers, Cyprinidae and Clariidae were the dominant families. Synodontis schall, L. nedgia, L. intermedius, C. gariepinus and $O$. niloticus were common in both seasons at Gibe and Wabe Rivers (Fig. 2). However, Heterobranchus longifilis Valenciennes, 1840 and L. forskalii were found only in Gibe River in both seasons. Moreover, in Gibe River, there were ten and six fish species during wet and dry seasons, respectively. Gibe River has ten species, which is greater than for the Wabe River (eight species) (Table 2). 
Table 2. Fish species composition of the Gibe and Wabe Rivers tributaries in the Gibe Sheleko National Park during the dry and wet season. Presence (+) and absence (-) of each species during the dry and wet seasons are presented relative to each river drainage

\begin{tabular}{|c|c|c|c|c|c|c|c|c|}
\hline \multirow[t]{3}{*}{ No. } & \multirow[t]{3}{*}{ Order } & \multirow[t]{3}{*}{ Family } & \multirow[t]{3}{*}{ Scientific Name } & \multirow{3}{*}{$\begin{array}{l}\text { Local Name } \\
\text { (Amharic) }\end{array}$} & \multicolumn{4}{|c|}{ Tributary } \\
\hline & & & & & \multicolumn{2}{|c|}{ Gibe } & \multicolumn{2}{|c|}{ Wabe } \\
\hline & & & & & $\overrightarrow{\bar{\theta}}$ & $\sum^{ \pm}$ & 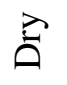 & $\stackrel{0}{3}$ \\
\hline 1. & Siluriformes & Mochokidae & $\begin{array}{l}\text { Synodontis } \\
\text { schall Bloch and Schneider, } \\
1801\end{array}$ & Qeqe & + & + & + & + \\
\hline 2. & Cypriniformes & Cyprinidae & $\begin{array}{l}\text { Labeobarbus nedgia Rüppell, } \\
1835\end{array}$ & Tseyimat & + & + & + & + \\
\hline 3. & Cypriniformes & Cyprinidae & $\begin{array}{l}\text { Labeobarbus intermedius } \\
\text { Rüppell } 1835\end{array}$ & Tseyimat & + & + & + & + \\
\hline 4. & Siluriformes & Clariidae & $\begin{array}{l}\text { Clarias gariepinus Burchell, } \\
1822\end{array}$ & Ambaza & + & + & + & + \\
\hline 5. & Perciformes & Cichlidae & $\begin{array}{l}\text { Oreochromis niloticus } \\
\text { Linnaeus, } 1758\end{array}$ & Birqe & + & + & + & + \\
\hline 6. & Siluriformes & Bagridae & Bagrus docmak Forsskål, 1775 & Keniya assa & + & - & + & - \\
\hline 7. & Cypriniformes & Cyprinidae & Labeo forskalii Rüppell, 1835 & Tseyimat & + & - & - & - \\
\hline 8. & Siluriformes & Clariidae & $\begin{array}{l}\text { Heterobranchus longifilis } \\
\text { Valenciennes, } 1840\end{array}$ & Zemetu & + & + & - & - \\
\hline 9. & Osteoglossiformes & Mutmut & $\begin{array}{l}\text { Mormyrus } \\
\text { kannume Forsskål, } 1775\end{array}$ & Mutmut & + & - & + & - \\
\hline 10. & Siluriformes & Korenti assa & $\begin{array}{l}\text { Malapterurus electricus } \\
\text { Gmelin, } 1789\end{array}$ & Korenti assa & + & - & + & - \\
\hline
\end{tabular}



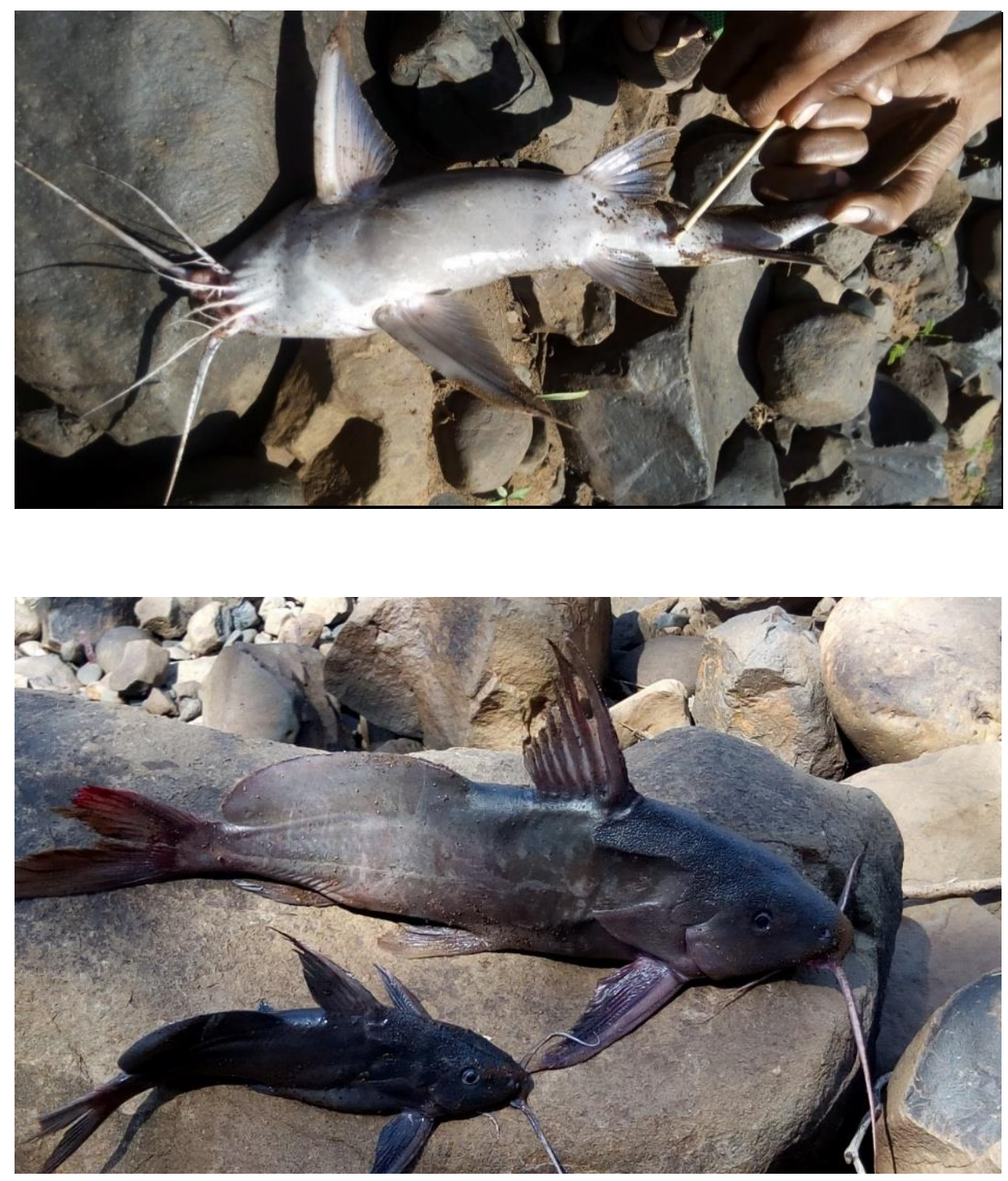

A. Ventral view and B. Lateral view of Synodontis schall

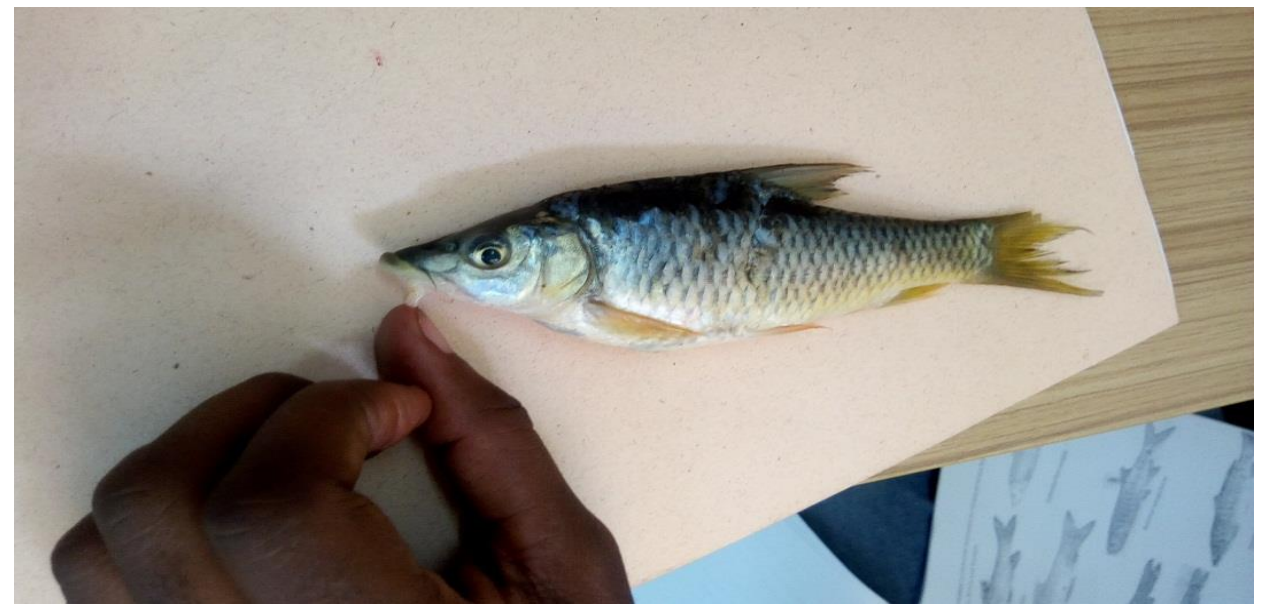

Labeobarbus nedgia 


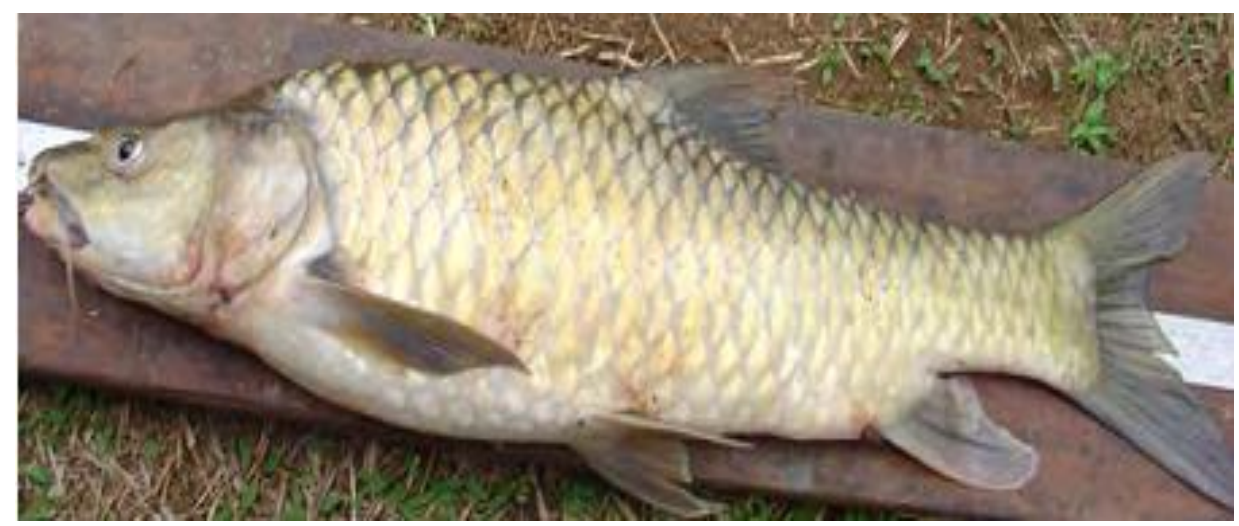

\section{Labeobarbus intermedius}

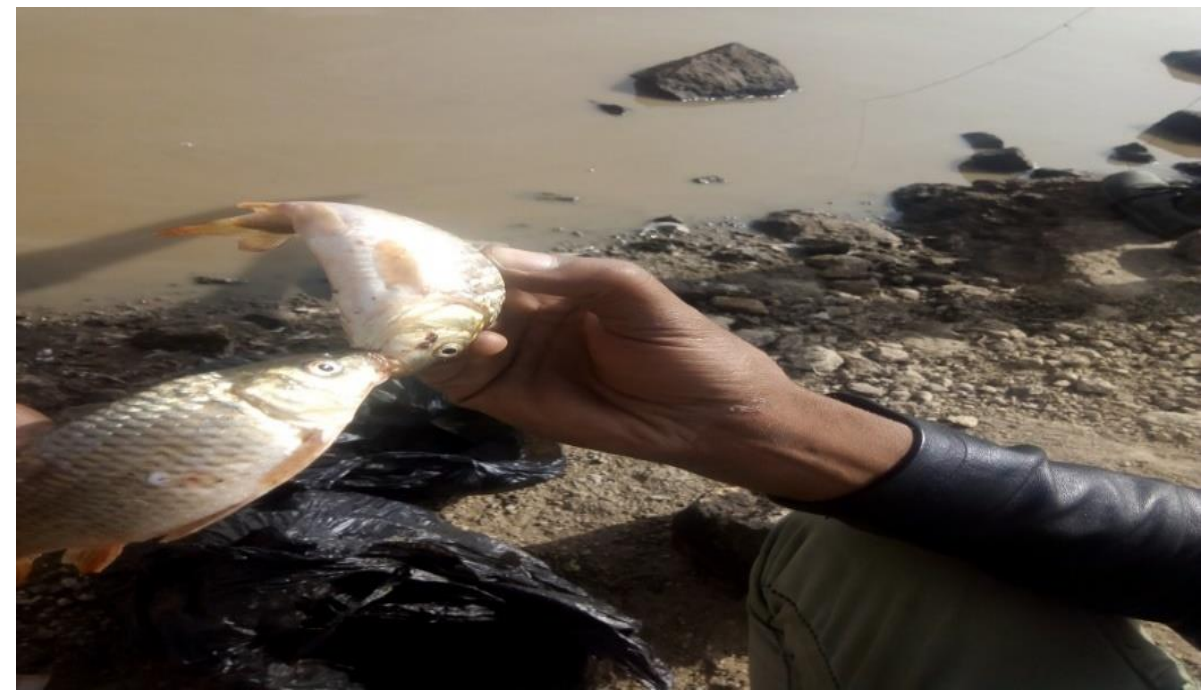

\section{Clarias gariepinus}

Figure 2: Fish species identified from Gibe Sheleko National Park Tributary

Morphometric measurements of identified fish species

Clarias gariepinus have large eye diameter $(8.4 \mathrm{~mm})$ followed by $S$. schall $(8.3 \mathrm{~mm})$ and $O$. niloticus $(7.5 \mathrm{~mm})$, but $L$. intermedius have the smallest eye diameter $(3.8 \mathrm{~mm}$ ) (see Table 3$)$. In the present study, $H$. longifilis was the first ranked fish, based on body length of fish which measured an average of $64.7 \mathrm{~cm}, 64.7 \mathrm{~cm}$ and $59.8 \mathrm{~cm}$ total, fork and standard length, respectively. However, based on body girth, $S$. schall was the largest $(23.1 \mathrm{~cm})$, followed by $B$. docmak $(21.7 \mathrm{~cm})$ and $C$. gariepinus $(20.3 \mathrm{~cm})$. Similarly, the body of $C$. gariepinus had a measured mean of $1713.4 \mathrm{~g}$ weight and was also the largest, followed by $S$. schall (1679.5 g) and B. docmak (987.8 g).

The eye diameter and the distance between eyes of the fish did not show statistical differences $(\mathrm{X} 2=80.0, \mathrm{df}=72, \mathrm{p}=0.242)$. Similarly, body weight of fish and girth were not statistically 
different $\left(\mathrm{X}^{2}=90.0, \mathrm{df}=81, \mathrm{p}=0.231\right)$. However, the pairwise comparison t-test showed that the total body length was not significantly different from the fork length $(\mathrm{t}=3.533$, $\mathrm{df}=9, \mathrm{p}=$ 0.006), but statistically different from standard length $(\mathrm{t}=5.54, \mathrm{df}=9, \mathrm{Pp}=0.00)$, weight $(\mathrm{t}=$ 7.37, $\mathrm{df}=9, \mathrm{p}=0.00)$ and girth $(\mathrm{t}=4.131, \mathrm{df}=9, \mathrm{p}=0.003)$.

Table 3. Body coloration and average morphometric measurements of identified specie.

\begin{tabular}{|c|c|c|c|c|c|c|c|c|c|}
\hline \multirow[t]{2}{*}{ No. } & \multirow[t]{2}{*}{ Fish Species } & \multirow[t]{2}{*}{ Coloration } & \multirow[b]{2}{*}{ 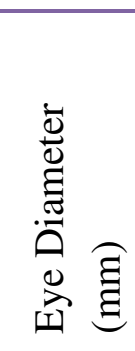 } & \multirow{2}{*}{ 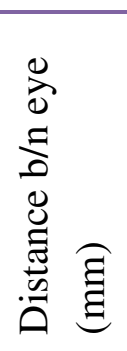 } & \multicolumn{3}{|c|}{$\begin{array}{l}\text { Average Body length } \\
(\mathrm{cm})\end{array}$} & \multirow[b]{2}{*}{ 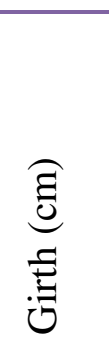 } & \multirow[b]{2}{*}{ 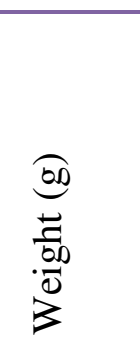 } \\
\hline & & & & & $\stackrel{\pi}{0}$ & 弟 & 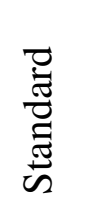 & & \\
\hline 1. & $\begin{array}{l}\text { Labeo } \\
\text { forskalii }\end{array}$ & $\begin{array}{l}\text { Dark olive above and } \\
\text { on the sides, white } \\
\text { beneath }\end{array}$ & 5.7 & 7.2 & 33.4 & 27.6 & 24.8 & 17.3 & 694.8 \\
\hline 2. & $\begin{array}{l}\text { Labeobarbus } \\
\text { intermedius }\end{array}$ & $\begin{array}{l}\text { Olive above, yellow or } \\
\text { pinkish beneath; fins } \\
\text { brown or olive }\end{array}$ & 3.8 & 8.1 & 56.6 & 52.3 & 49.7 & 17.2 & 957.7 \\
\hline 3. & $\begin{array}{l}\text { Labeobarbus } \\
\text { nedgia }\end{array}$ & $\begin{array}{l}\text { Olive or greenish grey } \\
\text { above, yellowish } \\
\text { beneath; fins olive or } \\
\text { grey. }\end{array}$ & 4.5 & 10.4 & 39.4 & 37.6 & 33.8 & 16.8 & 870.8 \\
\hline 4. & $\begin{array}{l}\text { Heterobranc } \\
\text { hus longifilis }\end{array}$ & $\begin{array}{l}\text { Olive above, white } \\
\text { beneath; adipose dorsal } \\
\text { fin often blackish at the } \\
\text { end }\end{array}$ & 5.8 & 12.3 & 64.7 & 64.7 & 59.8 & 18.4 & 897.3 \\
\hline 5. & $\begin{array}{l}\text { Bagrus } \\
\text { docmak }\end{array}$ & $\begin{array}{l}\text { Greyish blue to dark } \\
\text { olive above, white } \\
\text { beneath }\end{array}$ & 7.4 & 12.7 & 47.8 & 44.3 & 42.6 & 21.7 & 987.8 \\
\hline 6. & $\begin{array}{l}\text { Synodontis } \\
\text { schall }\end{array}$ & $\begin{array}{l}\text { Grey, brown, or olive } \\
\text { above; white beneath. }\end{array}$ & 8.3 & 14.1 & 41.5 & 30.5 & 27.5 & 23.1 & 1679.5 \\
\hline 7. & $\begin{array}{l}\text { Mormyrus } \\
\text { kannume }\end{array}$ & $\begin{array}{l}\text { Brownish or olive } \\
\text { above; white beneath }\end{array}$ & 5.8 & 9.7 & 42.3 & 38.6 & 37.1 & 17.5 & 912.8 \\
\hline 8. & $\begin{array}{l}\text { Oreochromis } \\
\text { niloticus }\end{array}$ & $\begin{array}{l}\text { Brown or grey to dark } \\
\text { olive colour }\end{array}$ & 7.5 & 9.1 & 19.2 & 18.8 & 16.9 & 15.7 & 659.7 \\
\hline 9. & $\begin{array}{l}\text { Malapterurus } \\
\text { electricus }\end{array}$ & $\begin{array}{l}\text { Olive above, yellow or } \\
\text { pinkish beneath; fins } \\
\text { brown or olive }\end{array}$ & 4.8 & 5.6 & 14.7 & 11.0 & 10.2 & 9.8 & 472.8 \\
\hline
\end{tabular}




\begin{tabular}{llllllllll}
\hline 10 & $\begin{array}{l}\text { Clarias } \\
\text { gariepinus }\end{array}$ & $\begin{array}{l}\text { Dark, grayish - black } \\
\text { above and creamy- } \\
\text { white below }\end{array}$ & 8.4 & 9.4 & 18.7 & 17.3 & 16.4 & 20.3 & 1713.4 \\
\hline
\end{tabular}

Relative abundance of fishes

A total of 249 fish specimens belonging to 10 species were collected from eight sampling sites during the study period. Of the total specimens collected, 179 were caught during the dry season and 70 specimens were caught during the wet season. There was significant difference in the mean number of fish specimens collected in the dry season $(t=3.943 \mathrm{df}=9, \mathrm{p}$ $=0.003)$. However, there were no obvious statistical differences in the mean number of specimens between rivers in the wet season total catch $(t=2.923, \mathrm{df}=9, \mathrm{p}=0.017)$. Moreover, the total catch of fish that were collected during the study period were not statistically different between dry and wet season $(\mathrm{F}=4.51, \mathrm{df}=1, \mathrm{p}=0.048)$. In this study, $S$. schall was the most abundant species in number, both in wet and dry seasons, followed by $L$. nedgia, L. intermediu and C. gariepinus and they contributed $28.52 \%, 18.88 \%, 14.06 \%$ and $10.44 \%$ of the total catch, respectively. Malapterurus electricus was only collected as two specimens and was the least abundant fish species (Table 4).

Table 4: Total catches of fishes and percentage (\%) of composition in dry and wet seasons. Some species were not found in wet season which represented as (-).

\begin{tabular}{llcccc}
\hline No. & \multicolumn{1}{c}{ Fish Species } & \multicolumn{2}{c}{ Season } & Total & \% composition \\
\cline { 3 - 4 } & & Dry & Wet & & \\
2 & Synodontis schall & 51 & 20 & 71 & 28.52 \\
2 & Labeobarbus nedgia & 32 & 15 & 47 & 18.88 \\
3 & Labeobarbus intermedius & 21 & 14 & 35 & 14.06 \\
4 & Clarias gariepinus & 16 & 10 & 26 & 10.44 \\
5 & Oreochromis niloticus & 14 & 9 & 23 & 9.23 \\
6 & Bagrus docmak & 18 & - & 18 & 7.23 \\
7 & Labeo forskalii & 10 & - & 10 & 4.02 \\
8 & Heterobranchus longifilis & 7 & 2 & 9 & 3.61 \\
9 & Mormyrus kannume & 8 & - & 8 & 3.21 \\
10 & Malapterurus electricus & 2 & - & 2 & 0.80 \\
& Total & $\mathbf{1 7 9}$ & $\mathbf{7 0}$ & $\mathbf{2 4 9}$ & $\mathbf{1 0 0}$ \\
\hline
\end{tabular}

Number of fish across the sites in each river for both seasons is indicated in Fig. 3. In both the Gibe and Wabe Rivers, the number of fish caught in the dry season was higher than during the wet season. In the Gibe River, the numbers of fish in all sites was higher in the dry season than the wet season, but in the Wabe River at site one, there were fewer fish than during the wet season. 


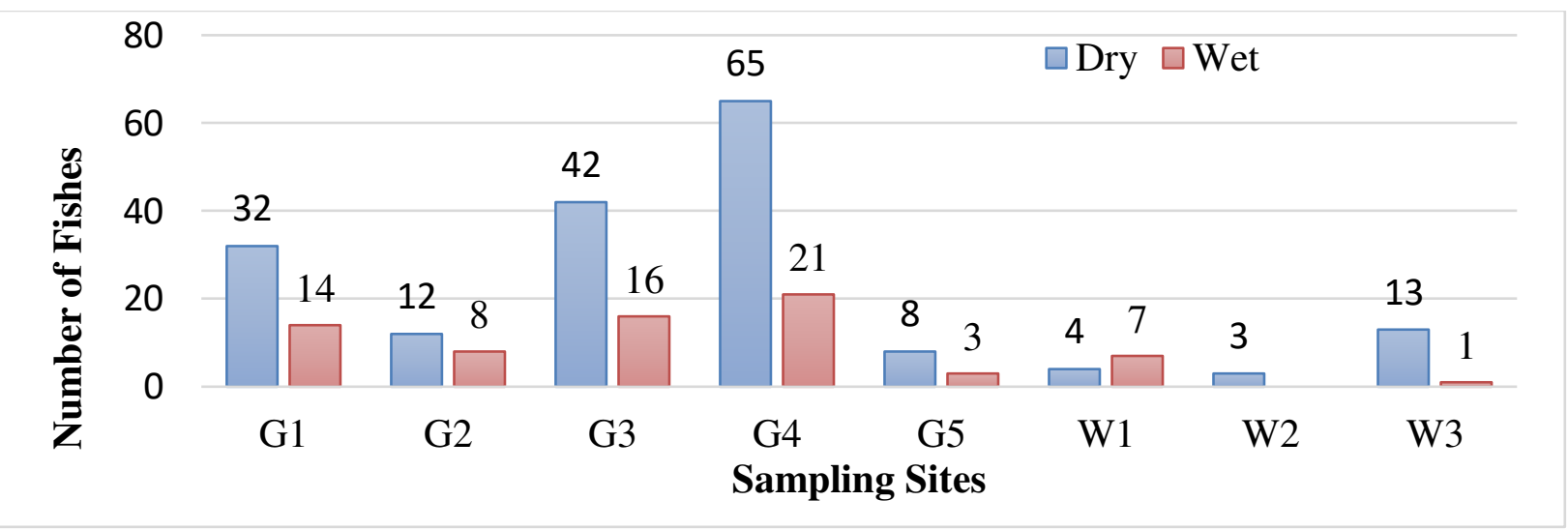

Figure 3: Total number or abundance of fishes recorded in eight sampling sites at Gibe (G1 to G5) and Wabe (W1 to W3) River sites in dry and wet seasons

Gibe River had more species diversity (10 species) than Wabe River (eight species) in the dry season and in the wet season (Gibe River, six species; Wabe River, five species (Fig. 4, Table 5). Accordingly, the Shannon Diversity Index $\left(\mathrm{H}^{\prime}\right)$ was highest in the Gibe River with a value of $\left(\mathrm{H}^{\prime}=2.09\right)$ compared to the Wabe River $\left(\mathrm{H}^{\prime}=1.84\right)$ during the dry season. However, $\mathrm{H}^{\prime}$ was highest in the Wabe River $\left(\mathrm{H}^{\prime}=\right.$ 1.57) during the wet season (Gibe River, $\mathrm{H}^{\prime}=1.52$ ). Moreover, both the number of species $(\mathrm{N})$ and Shannon Diversity Index $\left(\mathrm{H}^{\prime}\right)$ were not statistically different between the Gibe and Wabe Rivers $\mathrm{F}=$ 0.36 , df $=1, \mathrm{p}=0.609$ and $\mathrm{F}=0.101, \mathrm{df}=1, \mathrm{p}=0.781$, respectively. Similarly, between dry and wet seasons there were no obvious statistical differences of $\mathrm{N}$ and $\mathrm{H}^{\prime}$ values $\mathrm{F}=9.80, \mathrm{df}=1, \mathrm{p}=0.89$ and $\mathrm{F}$ $=10.855, \mathrm{df}=1, \mathrm{p}=0.81$, respectively.

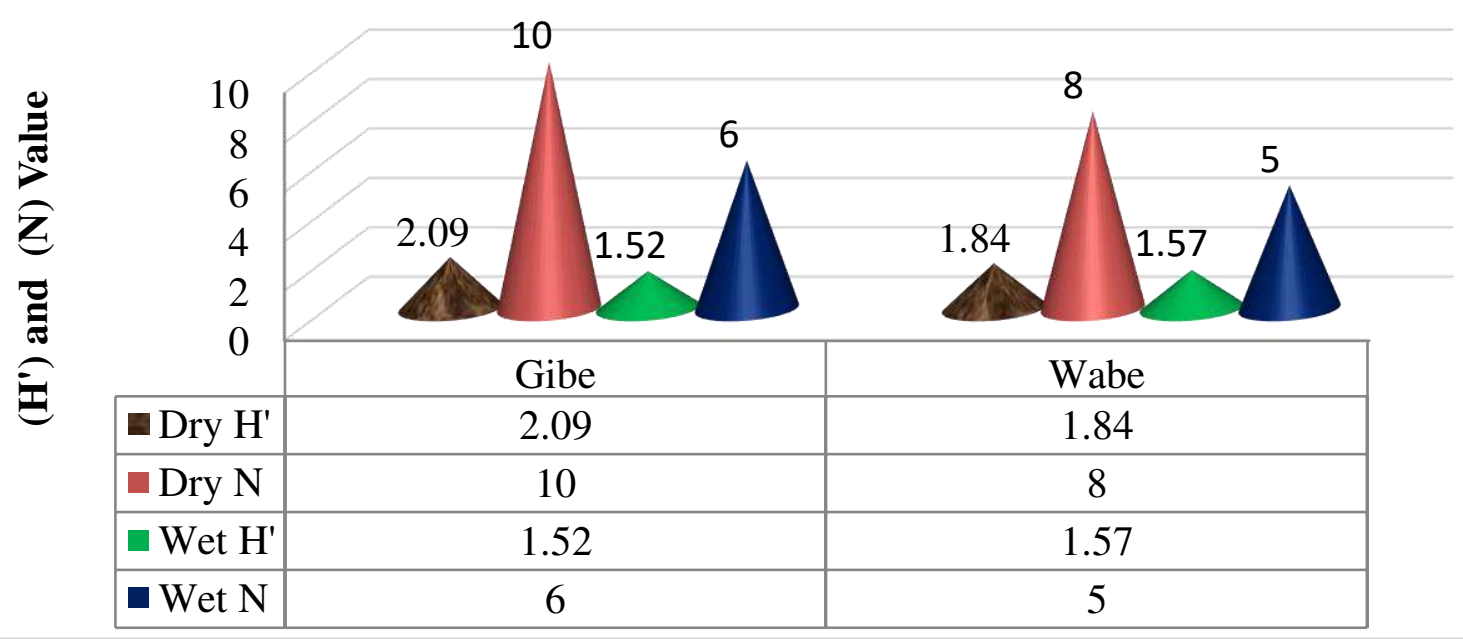


Figure 4: Shannon diversity index $\left(\mathrm{H}^{\prime}\right)$ and number of fish species $(\mathrm{N})$ in Gibe and Wabe River of GSNP during wet and dry season.

The species composition of all catches, both in dry and wet seasons, were analysed and ranked, based on the Index of Relative Importance (IRI). According to IRI, the most important species in the total catches were S. schall (49.13\%), L. intermedius (15.49\%), C. gariepinus (11.70\%) and L. nedgia (9.97\%). However, there was no significant differences between fish species of IRI values $\left(X^{2}=90.0, d f=81, p=\right.$ $0.231)$.

Table 5: Number (N) and index of relative importance (IRI) of fishes in the study area. \% Wi and $\% \mathrm{Ni}=$ percentages in weight and number of each species of total catch. $\% \mathrm{Fi}=$ percentage frequency occurrence of each species in total number of settings. $\% \mathrm{Wj}$ and $\mathrm{Nj}=$ percentages in weight and number of total species in total catch. $F j=$ percentage frequency of occurrence of total species in total number of settings).

\begin{tabular}{|c|c|c|c|c|c|c|c|c|c|}
\hline No. & Fish Species & $\mathbf{N}$ & $\% \mathrm{~N}$ & W & $\% \mathrm{~W}$ & $\mathbf{F}$ & $\% \mathrm{~F}$ & IRI & \%IRI \\
\hline 1. & Synodontis schall & 71 & 28.52 & 119244.5 & 40.50 & 14 & 20.0 & 1380.4 & 49.13 \\
\hline 2. & $\begin{array}{l}\text { Labeobarbus } \\
\text { intermedius }\end{array}$ & 35 & 14.06 & 33519.5 & 11.38 & 12 & 17.14 & 435.04 & 15.49 \\
\hline 3. & $\begin{array}{l}\text { Clarias } \\
\text { gariepinus }\end{array}$ & 26 & 10.44 & 44548.4 & 15.13 & 9 & 12.86 & 328.83 & 11.70 \\
\hline 4. & $\begin{array}{l}\text { Labeobarbus } \\
\text { nedgia }\end{array}$ & 47 & 18.88 & 40927.6 & 13.90 & 6 & 8.57 & 280.02 & 9.97 \\
\hline 5. & $\begin{array}{l}\text { Oreochromis } \\
\text { niloticus }\end{array}$ & 23 & 9.23 & 15173.1 & 5.15 & 7 & 10.0 & 143.80 & 5.12 \\
\hline 6. & Bagrus docmak & 18 & 7.23 & 17780.4 & 6.04 & 6 & 8.57 & 113.72 & 4.05 \\
\hline 7. & Labeo forskalii & 10 & 4.02 & 6948 & 2.36 & 7 & 10.0 & 63.8 & 2.27 \\
\hline 8. & $\begin{array}{l}\text { Heterobranchus } \\
\text { longifilis }\end{array}$ & 9 & 3.61 & 8075.7 & 2.74 & 4 & 5.71 & 36.26 & 1.29 \\
\hline 9. & $\begin{array}{l}\text { Mormyrus } \\
\text { kannume }\end{array}$ & 8 & 3.21 & 7302.4 & 2.48 & 3 & 4.29 & 24.41 & 0.87 \\
\hline
\end{tabular}




\begin{tabular}{llllllllll}
\hline $\mathbf{1 0}$ & $\begin{array}{l}\text { Malapterurus } \\
\text { electricus }\end{array}$ & 2 & 0.80 & 945.6 & 0.32 & 2 & 2.86 & 3.20 & 0.11 \\
Total & $\mathbf{2 4 9}$ & $\mathbf{1 0 0}$ & $\mathbf{2 9 4 4 6 5 . 2}$ & $\mathbf{1 0 0}$ & $\mathbf{7 0}$ & $\mathbf{1 0 0}$ & $\mathbf{2 8 0 9 . 4 8}$ & $\mathbf{1 0 0}$ \\
\hline
\end{tabular}

\section{Fishery activities}

The fishermen in the study area have been involved in fishing for 6-15 hours within a day and there are seasonal fishermen who fish from the river only for consumption. Fishing in the study area is mainly artisanal and fish are sold at the local market. The commercially-important species are $S$. schall, L. nedgia, L. intermedius, C. gariepinus and O. niloticus. The fisher folk use locally-available gear, such as single hook and line and mosquito net (Fig. 5). In addition, Birbira (Milletia ferruginea) seed powder is also used to anaesthetise and collect the fish.

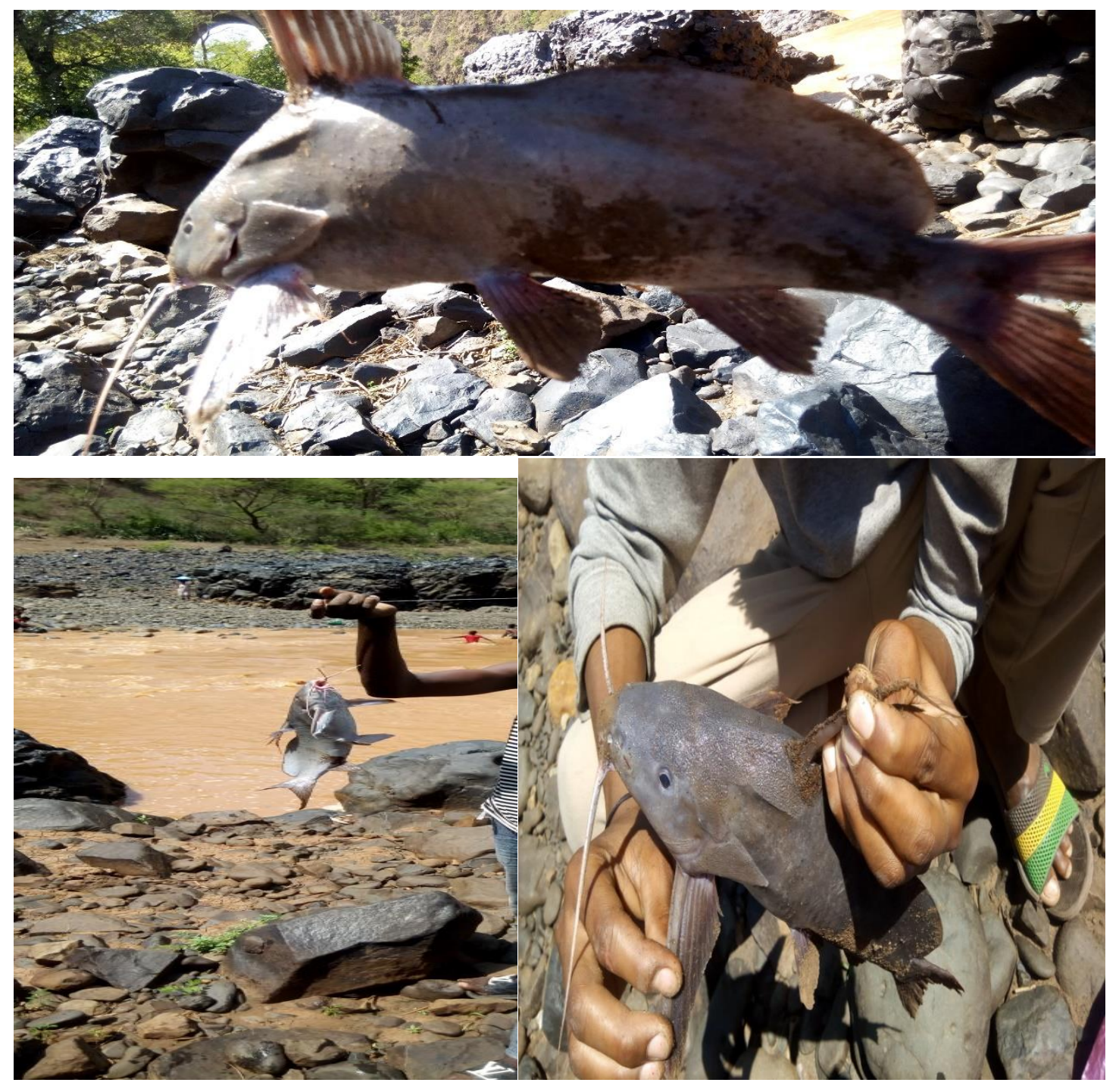

Figure 5: Fishing activity in the study area by using single hook 


\section{DISCUSSION}

The present study revealed 10 species, belonging to a single class Actinopterygii (ray-finned fishes), four orders and seven families in GSNP tributary rivers. The richness is lower than those reported from certain other rivers of Ethiopia. For example, the reports mentioned 23 fish species belonging to seven families and five orders from the Beles and Gilgel Beles Rivers (Getahun et al. 2020), 13 species (belonging to three families from the in Gilgel Abay and Andassa Rivers (Aynalem et al. 2018) and Oumer et al. (2011) reported the occurrence of 17 species in the head of the Blue Nile River. However, other researchers have reported less diversity of fish in other water bodies compared to the diversity of Gibe and Wabe Rivers of GSNP, such as Urga et al. (2017) identified five species with one family in Debbis River and Melaku et al. (2017) identified nine species of fin-fish representing seven genera and four families from Geba and Sor Rivers.

A total of three species of fish were observed belonging to the order Cypriniformes and family Cyprinidae. The members of this family are distributed in freshwater habitats all over the world (Nikam et al. 2014). Cyprinidae was the dominant family consistent with the earlier findings of DeGraaf (2003), Melaku et al. (2017), Urga et al. (2017), Aynalem et al. (2018), Getahun et al. (2020). The presence dominance of the few families in this study gave the impression that these cyprinid fishes, being riverine origin, are specifically segregated or adapted in the Gibe-Omo Basin and its tributaries in Ethiopia. The fish species compositions between Gibe and Wabe River might be due to special adaption of the riverine cyprinids. Cyprinids are the dominant family; especially L. intermedius and L. nedgia were common in most of the Ethiopian inland water bodies previously reported DeGraaf (2003), Oumer et al. (2011), Mequaninnet et al. (2014).

Of the total ten species, ten and eight species were identified from Gibe and Wabe Rivers of GSNP, respectively. Synodontis schall, L. nedgia, L. intermedius and C. gariepinus were the most dominant fish species in GSNP tributaries. The less diversity (10 species) in the present study might be due to the length of the sampling periods (i.e. this investigation was carried out in two seasons over relatively short periods of time, while others studies were over a long period) and fishing gear used have a high selective effect (Limbu et al. 2018). The second reason for the less diversity reported now might be the effect of flow variability on fish assemblage, for example, high flows could destroy fish habitat and wash away the already-laid fish eggs. The other reason might due to the fact that fish diversity decreases drastically in the upper parts of the rivers as in other Ethiopian basins (Golubtsov and Mina 2003). Gibe River has more species diversity in both dry and wet seasons. There might be several reasons for variation in abundance between tributaries. Variation in available nutrients and habitats, temperature, fishing effort, fish behaviour, size and life history stages of fishes and others might have contributed to the variation in abundance of the catches (Begon et al. 1990, Stiassny and Getahun 2007).

In all sampling sites, the number of fish was higher during the dry season than the wet season (Table 4, Fig. 3). The reason for such variations could be probably due to the high turbidity of the river water, velocity of the water and low temperature during wet season which may have attributed to the less number of fish caught (DeGraaf 2003). During wet season, there was also higher water discharge; fish could have highly dispersed in the large volume of water in this 
season as compared to the dry season, making them more difficult to catch. (Tesfaye and Wolff 2014). In addition, the variation in catches between wet and dry seasons might be due to the efficiency of the gill-net and time of setting of the gill-net. Wood logs, leaves, roots and grasses which were brought by flooding, could have decreased the efficiency of gill-nets during the wet season. Generally, the fish diversity in both rivers was not the same in wet and dry seasons, like the results reported by Melaku et al. (2017) in Geba and Sor Rivers Rivers and Tewabe et al. (2010) in Ayima, Guang, Shinfa and Gendwuha Rivers where fish diversity was higher in the dry season than the wet season. High density in shallower pools in the dry season and the ease of their collection using the available fishing gear could be a reason for the high diversity (Oumer et al. 2011, Mequaninnet et al. 2014, Tewabe et al. 2010).

The Shannon Diversity Index was used to evaluate species diversity of sampling sites and rivers. It also explains both variety and the relative abundance of fish species (Naesje et al. 2004). The Shannon Diversity Index $\left(\mathrm{H}^{\prime}\right)$ also was higher in the dry season than the wet season in Gibe River and Wabe River. According to the IRI, the most important species in the total catches were $S$. schall, followed by L. intermedius, $C$. gariepinus and L nedgia, respectively. Moreover, differences in sampling habitats, fishing effort, type of gear and gill-net efficiency, sampling seasons and altitude might have contributed to the variation in the catch rates and species diversity (Awoke 2015, Awoke et al. 2015, Abera et al. 2018).

As mentioned above, there might be several reasons for variation in abundance between wet and dry seasons. Variation in available nutrients and habitats, temperature, fishing effort, fish behaviour, size and life history stages of fishes and others might have contributed to the variation in abundance of the catches. Moreover, water level (Karenge and Kolding 1995) and turbidity of water may also affect abundance (DeGraaf 2003). Flow variability might also have an effect on fish assemblages. For example, high flows could destroy fish habitat and wash away any spawned fish eggs. Differences in sampling habitats (river width, substrate type, source distance and depth), fishing effort, type of gear and gill-net efficiency, sampling seasons and altitude might have contributed to the variation in the catch rates and species diversity (Karenge and Kolding 1995, Gebremariam et al. 2002, DeGraaf 2003). However, observed differences in morphometric characteristics measured in the present study, when compared with those obtained by other authors, are likely due to differences in the number of specimens examined, differences in the utilised length ranges or differing study seasons, food availability, feeding rate, gonad development and spawning period (Teferi et al. 2002, Tewabe et al. 2010).

\section{Conclusion and Recommendations}

A total of ten fish species belonging to five orders and six families were identified from Gibe and Wabe River of GSNP. The fish diversity of GSNP is dominated by Cyprinidae fish species. Synodontis schall, L. nedgia, L. intermediu and C. gariepinus were the dominant fish species in GSNP tributaries. Gibe River has more species diversity in both dry and wet seasons. The Shannon Diversity Index $\left(\mathrm{H}^{\prime}\right)$ was also higher in the dry season than the wet season in Gibe River and Wabe River. According to IRI, the most important species in the total catches were $S$. schall, followed by L. intermedius, C. gariepinus and L. nedgia, respectively. Moreover, differences in sampling habitats, fishing effort, type of gear and gill-net efficiency, sampling 
seasons and altitude might have contributed to the variation in the catch rates and species diversity. Therefore, the present study proposes the following recommendations:

$>$ There should be a detailed study on the diversity, relative abundance and biology of fish species in the upper streams of both rivers.

$>$ Year-round data should be collected to give a clear understanding on the reproductive biology of fish

$>$ Further studies are needed on food and feeding, reproductive behaviour of fish species and socioeconomic aspects of fisheries.

$>$ Fishery development should be implemented in both Rivers to use the fish resource sustainably without affecting the by-catch.

$>$ In addition, training should be given for local people living around the rivers on how to catch fish with legal fishing gear and how to prepare fish dishes by Wolkite University and Gibe Sheleko National Park office.

$>$ Fish sport activities should be established in the Park to attract tourists.

$>$ The development of aquaculture and other related alternative fisheries should be encouraged to reduce the pressure on the natural system.

\section{Acknowledgement}

We would like to thank Wolkite University for providing the budget logistic. We special appreciation goes to Gibe Sheleko National Park staff members for their great help during sampling and data collection.

\section{Declaration}

Data Availability Statement: The authors affirm that there is no separate available data file. All data necessary for confirming the conclusions of the article are present within the article, figures and tables.

\section{Authors' Contribution}

SM and AH conceived and designed the investigation. SM and AH collected the data. While, SM was analyzed the data and wrote the paper. 


\section{Ethics declarations}

\section{Ethics approval and consent to participate}

Permits for this research were issued by the Ethiopian Wildlife Conservation Authority (EWCA), Wolkite University (www.wku.edu.et) and Gibe Sheleko National Park management office. Capture and sampling was conducted in accordance with the guideline of Ethiopian Wildlife Conservation Authority proclamation number 41/1993 and Gibe Sheleko National Park management office. The study was approved by Research, Publication and Technology Transfer Committee of College of Agriculture and Natural Resource under Wolkite University with the approval reference number RCUILC-CANR01/2011.

\section{Consent for publication}

Not applicable.

\section{Conflict of Interest}

To the authors' knowledge, no conflict of interest exists. That is, no interest or relationship, financial or otherwise that might be perceived as influencing an author's objectivity exists.

\section{References}

Abera L, Getahun A, Lemma B (2018). Changes in Fish Diversity and Fisheries in Ziway-Shala Basin: The Case of Lake Ziway, Ethiopia. J Fisheries Livest Prod 6: 263. doi: $10.4172 / 2332-2608.1000263$

Amare, A. (2015) Conservation Challenges of Gibe Sheleko National Park, Southwestern Ethiopia. Natural Resources, 6, 286-289. http://dx.doi.org/10.4236/nr.2015.64025

Awoke, T. M. (2015). Fish species diversity in major river basins of Ethiopia: A review. World Journal of Fish and Marine Sciences 7 (5): 365-374. https://doi.org/10.5829/idosi.wjfms.2015.7.5.95195

Awoke, T., Mingist, M. and Getahun, A. (2015). Abundance and species compositions of fishes in Blue Nile River, Ethiopia. International Journal of Fisheries and Aquatic Studies 2 (6): 334-339.

Aynalem, Y., Mingist, M. and Getu, A. (2018). Diversity, relative abundance, species composition and some biological aspects of fishes in gilgel abay and Andassa Rivers, 
Blue Nile Basin, Ethiopia. Fisheries and Aquaculture Journal 9: 241. doi:10.4172/21503508.1000241

Begon M, Harper JL, Townsed CR. (1990). Ecology: individuals, population and communities. 2nd Ed. Blackwell Scientific Publication, 945pp. University Saints Malaysias, Penang, Malaysia, 1990, 6.

DeGraaf M. (2003). Lake Tana's piscivorous Barbus (Cyprinidae, Ethiopia): Ecology, evolution and exploitation. Wageningen University, Wageningen, 256 pp. [ISBN 90-5808-938-x].

Gebremariam, Z., Kebede, W.E. and Desta, Z. (2002). Long-term changes in chemical features of waters of seven Ethiopian Rift-valley lakes. Hydrobiology, 477: 8191. https://doi.org/10.1023/A:1021061015788

Getahun, A., Bereie, Z. and Dejen, E. (2020). Diversity of fishes in Beles and Gilgel beles Rivers, abay basin, Ethiopia. International Journal of Aquaculture and Fishery Sciences 6(3): 068-073. DOI: https:// dx.doi.org/10.17352/2455-8400.000059

Getahun, A., (2007). An overview of the diversity and conservation status of the Ethiopian freshwater fish fauna. Journal of Afrotropical Zoology special Issue: 87-96.

Golubtsov, A. S., and Darkov, A. A. (2008). A review of fish diversity in the main Drainage systems of Ethiopia, pp. 69-102. In: Ecological and Faunistic Studies in Ethiopia (Pavlov, S. D., Y.Y., Dgebuadze, A. A., Darkov, S. A., Golubtsov, and V. M. Mina, Eds.). Moscow: KMK Scientific Press.

Golubtsov, A. S., and Mina, J. (2003). Fish species diversity in the main drainage systems of Ethiopia: Current state of knowledge and research prospective. Ethiopian Journal of Natural Resources, 5: 281-318.

Karenge L, Kolding J. (1995). Inshore fish population and species changes in Lake Kariba, Zimbabwe. In: Pitcher, T., Hart, P.J.B. (Eds.), The Impact of Species Changes in African Lakes. Fish and Fisheries Series, vol. 18. Chapman and Hall, London, 1995, 245-275. https://doi.org/10.1007/978-94-011-0563-7_12

Kebede, A., Meko, T., Hussein, A. and Tamiru Y. (2017). Review on Opportunities and Constraints of Fishery in Ethiopia. International Journal of Poultry and Fisheries Sciences, 1(1):1-8. https://doi.org/10.15226/2578-1898/1/1/00104 
Limbu, J.H., Shrestha,O.H. and Prasad, A. (2018). Ichthyofaunal diversity of Bakraha River of Morang district, Nepal. International Journal of Fisheries and Aquatic Studies, 6(5): $267-271$

Melaku, S., Getahun, G. and Wakjira, M. (2017). Population Aspects of Fishes in Geba and Sor Rivers, White Nile System in Ethiopia, East Africa. Hindawi International Journal of Biodiversity 2017 (1): 1-7. https://doi.org/10.1155/2017/1252604

Mequaninnet, D., Mingist, M., Getahun, A. and Anteneh, W. (2014). Spawning migration of Labeobarbus species of Lake Tana to Gilgel Abay River and its tributaries, Blue Nile Basin, Ethiopia. African Journal of Fisheries Science 2 (9): 176-184.

Naesje TF, Hay CJ, Nickansor N, Koekemoer JH, Strand R, Thorstad EB. (2004). Fish population, gillnet catch and gillnet selectivity in the Kwando River. Namibia. Norwegian Institute for Nature Research. Tungasletta 2 (7485): 1-64.

Nagelkerke, L.A.J. (1997). The Barbus of Lake Tana, Ethiopia: Morphological diversity and its implication for taxonomy, trophic resource partitioning and fisheries. $\mathrm{PhD}$ Thesis, Agricultural University, Wageningen, the Netherlands, 298 pp. [ISBN 9789054857556 296].

Nikam, D.S., Shaikh, A.L., Salunkhe, P.S., Kamble,A.B. and Rao, K.R. (2014). Ichthyofaunal Diversity of Ashti Lake, Tal. Mohol, Dist. Solapur (M.S.). The Global Journal of Pharmaceutical Research, 3 (12), 4-5.

Oumer, M., Mingist, M. and Dejen, E. (2011). Divesity and relative abundance of fishes in the head of Blue Nile River, Ethiopia. Ethiopian Journal of Biological Sciences, 10(2): 207212 ISSN: 1819-8678 2011.

Sanyanga, R.A. (1996). Variation in abundance of Synodontis zambezensis (Pisces: Mockokidae) Peters 1852, in the shore fishery of Lake Kariba. Fisheries Research. 1996; 26:171-186.

Stiassny, M. and Getahun, A. (2007). An overview of labeon in relationship and the phylogenetic placement of the Afro-Asian genus Garra Hamiltin, 1922 (Teleostei: Cyprinidae), with the description of the five new species of Garra from Ethiopia, and a key to all African species. Zoological Journal of the Linnran Society 150: 41-83. 
Teferi, Y., Admassu, D. and Mengistu, S. (2002). Length-weight relationship, Body condition and sex ratio of tilapia (Oreochromis niloticus) in Lake Chamo, Ethiopia. SINET: Ethiopian Journal of Science 25 (1): 19-26.

Temesgen, M.K. and Getahun, A.G. (2016). Fishery management problems in Ethiopia: Natural and human induced impacts and the conservation challenges. Reviews in Fisheries Science and Aquaculture, 24:4, 305-313, DOI: 10.1080/23308249.2016.1187582

Tesfaye, G. and Wolff, M. (2014). The state of inland fisheries in Ethiopia: A synopsis with updated estimates of potential yield. Ecohydrology andHydrobiology 14 (3): 200-219. https://doi.org/10.1016/j.ecohyd.2014.05.001

Tewabe, D., Getahun, A. and Dejen, E. (2010). Fishing activities in Gendwuha, Guang, Shinfa and Ayima rivers in Tekeze and Abbay basins, Ethiopia: preliminary study. Ecohydrology and Hydrobiology 10 (24), 333-340.

Tilahun, B., Abie, K., Feyisa,A. and Amare, A. (2017). Attitude and perceptions of local communities towards the conservation value of Gibe Sheleko National Park, Southwestern Ethiopia. Agricultural and Resource Economics: International Scientific EJournal, 3(2), 65-77

Urga, K.T., Prabhadevi, L., and Tedesse, Z. (2017). Diversity and biology of fishes in the river Debbis, Ethiopia, International Journal of Aquaculture, 7(20):126-133. doi:10.5376/ija.2017.07.0020. 


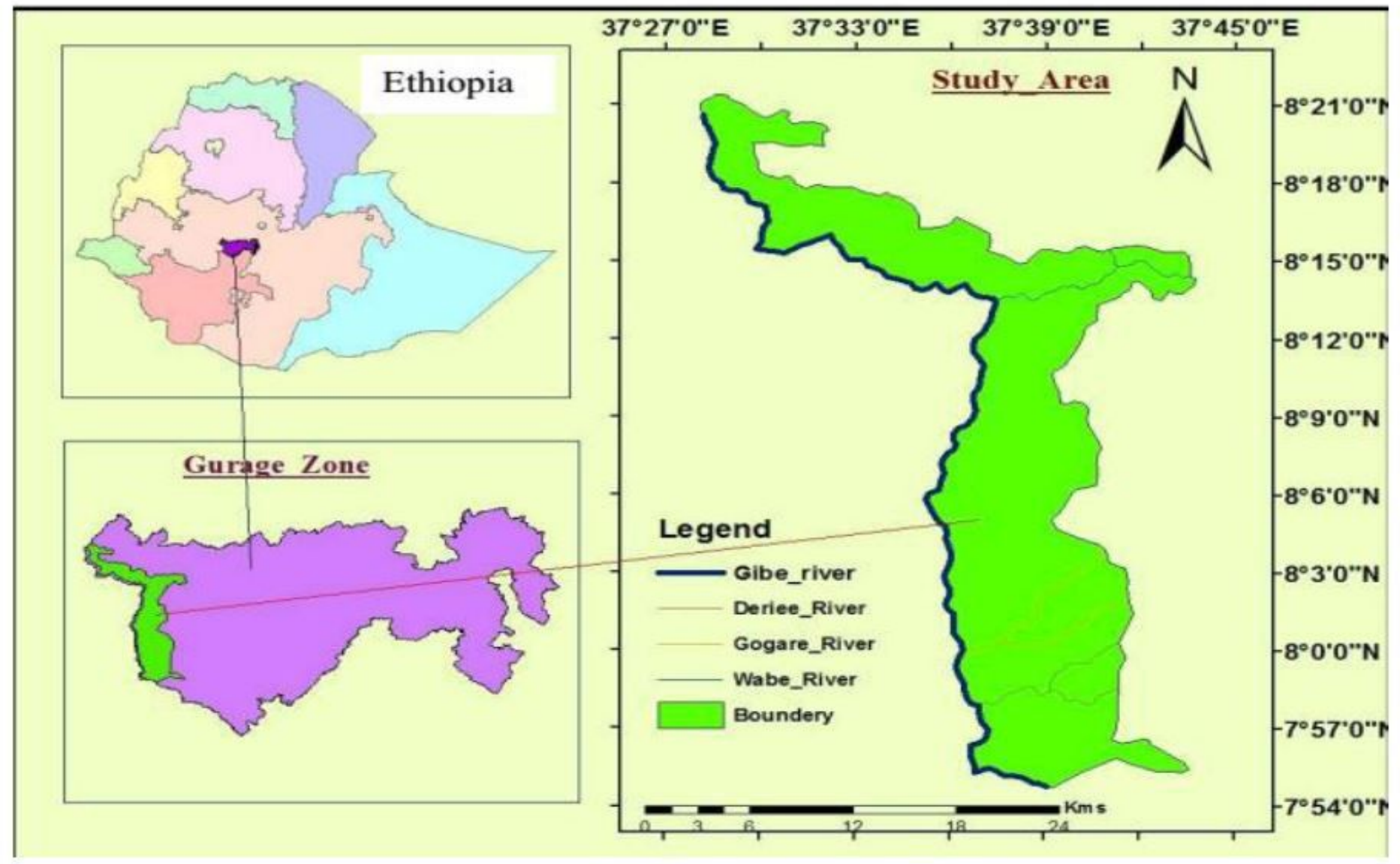

\section{Figure 1}

Map of Gibe Sheleko National Park (Source: Belete et al., 2017) Note: The designations employed and the presentation of the material on this map do not imply the expression of any opinion whatsoever on the part of Research Square concerning the legal status of any country, territory, city or area or of its authorities, or concerning the delimitation of its frontiers or boundaries. This map has been provided by the authors. 

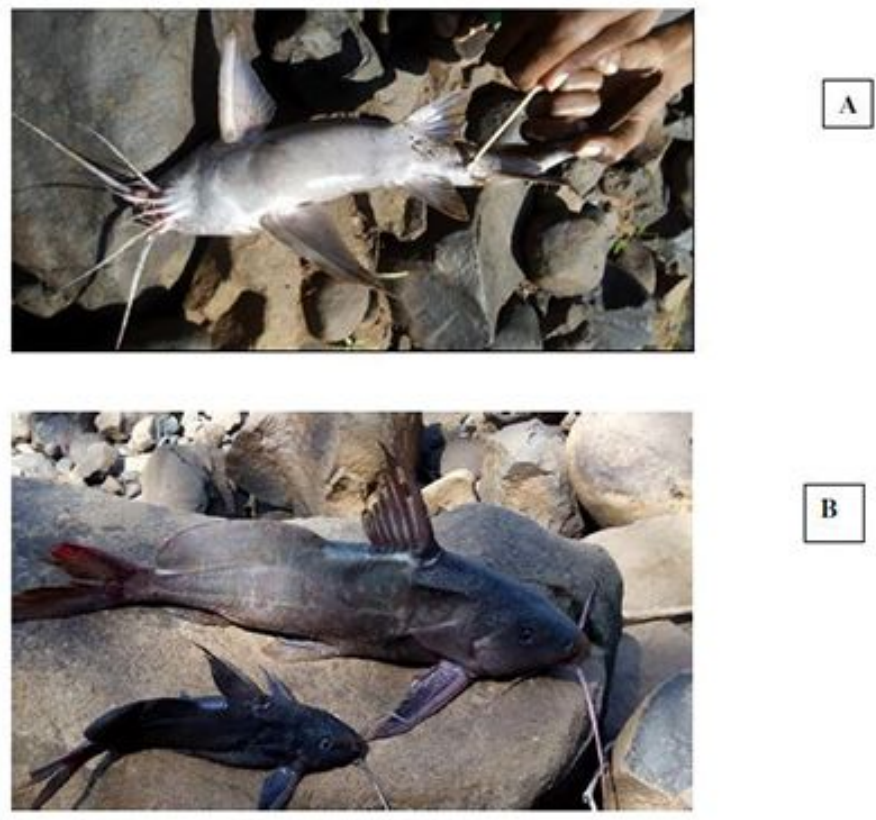

B

A. Ventral view and B. Lateral view of Synodontis schall

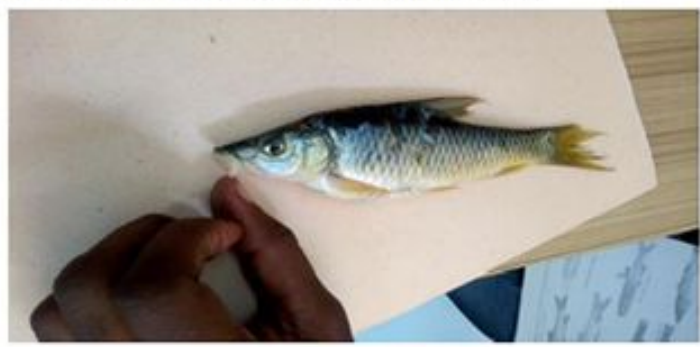

Labeobarbus nedgia

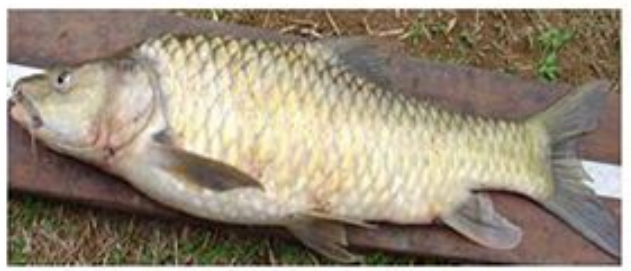

Labeobarbis intermedius

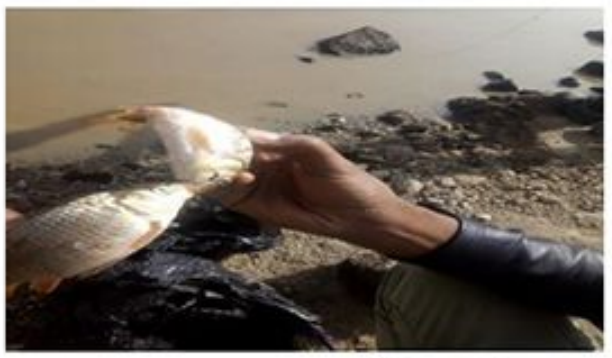

Clarias gariepinus

Figure 2

Fish species identified from Gibe Sheleko National Park Tributary 


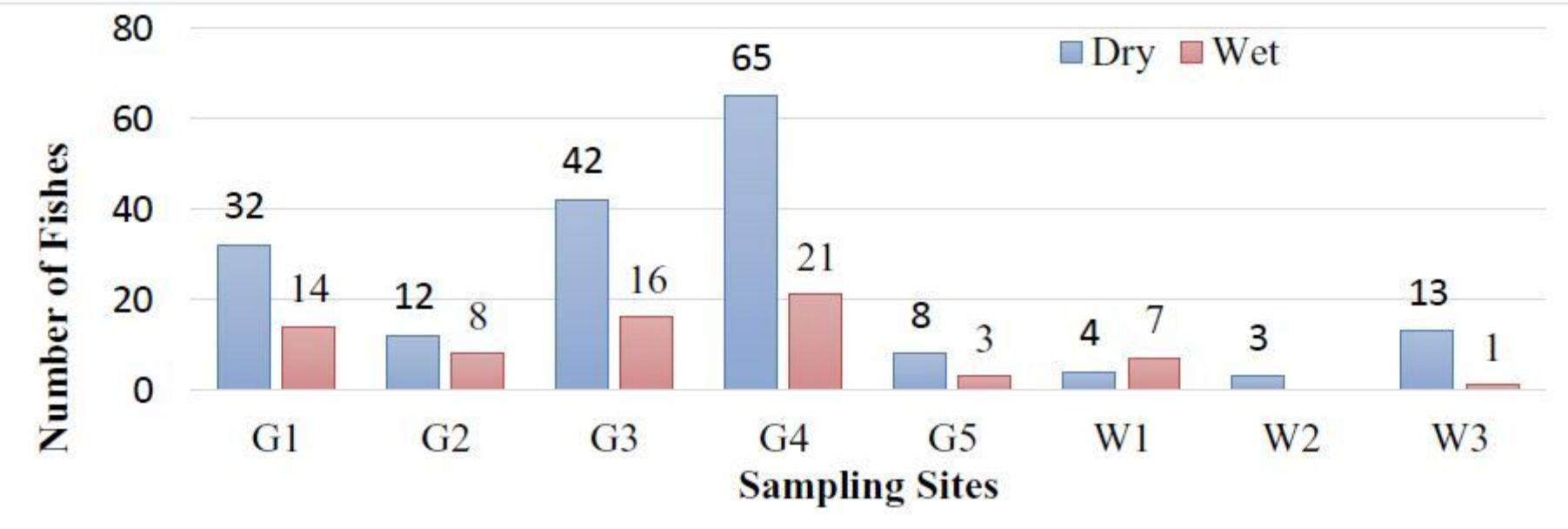

Figure 3

Total number or abundance of fishes recorded in eight sampling sites at Gibe (G1 to G5) and Wabe (W1 to W3) River sites in dry and wet seasons

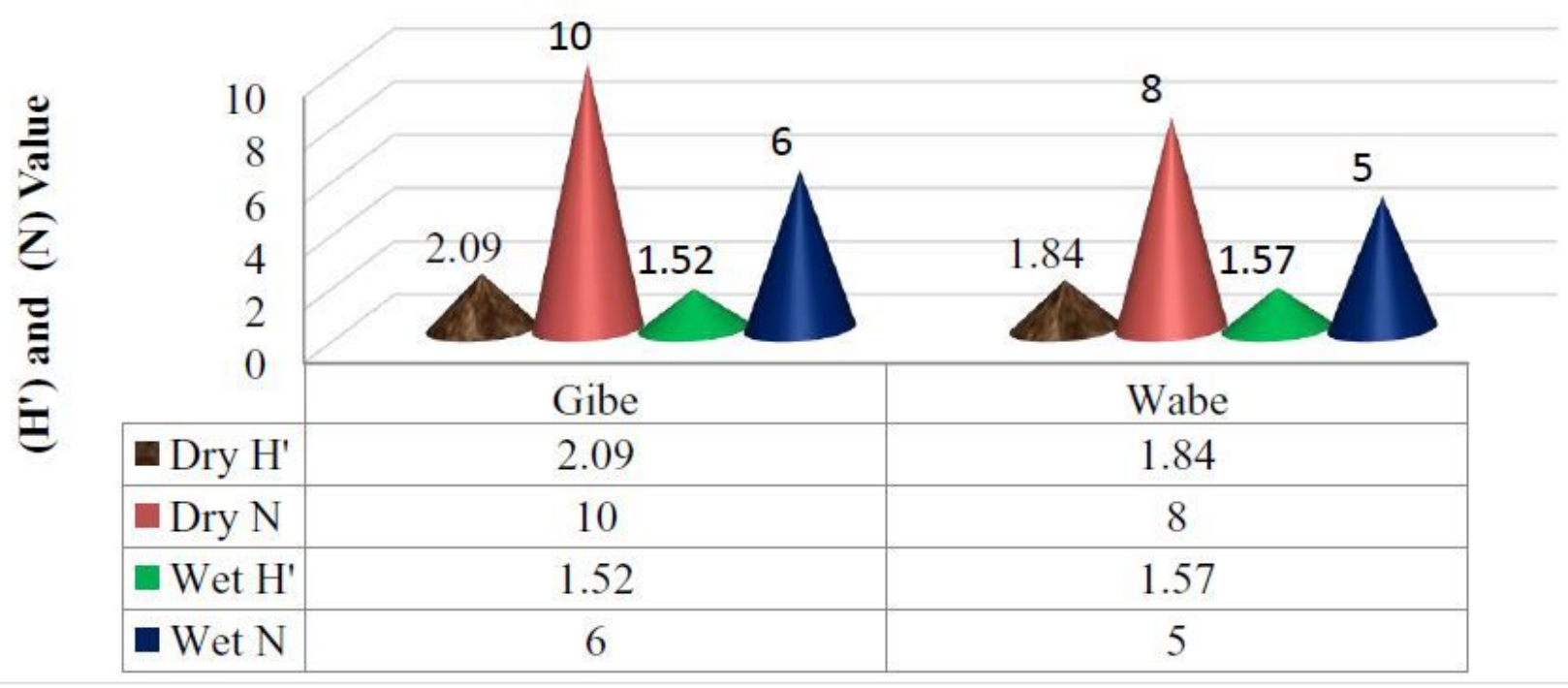

Figure 4

Shannon diversity index $\left(\mathrm{H}^{\prime}\right)$ and number of fish species $(\mathrm{N})$ in Gibe and Wabe River of GSNP during wet and dry season. 


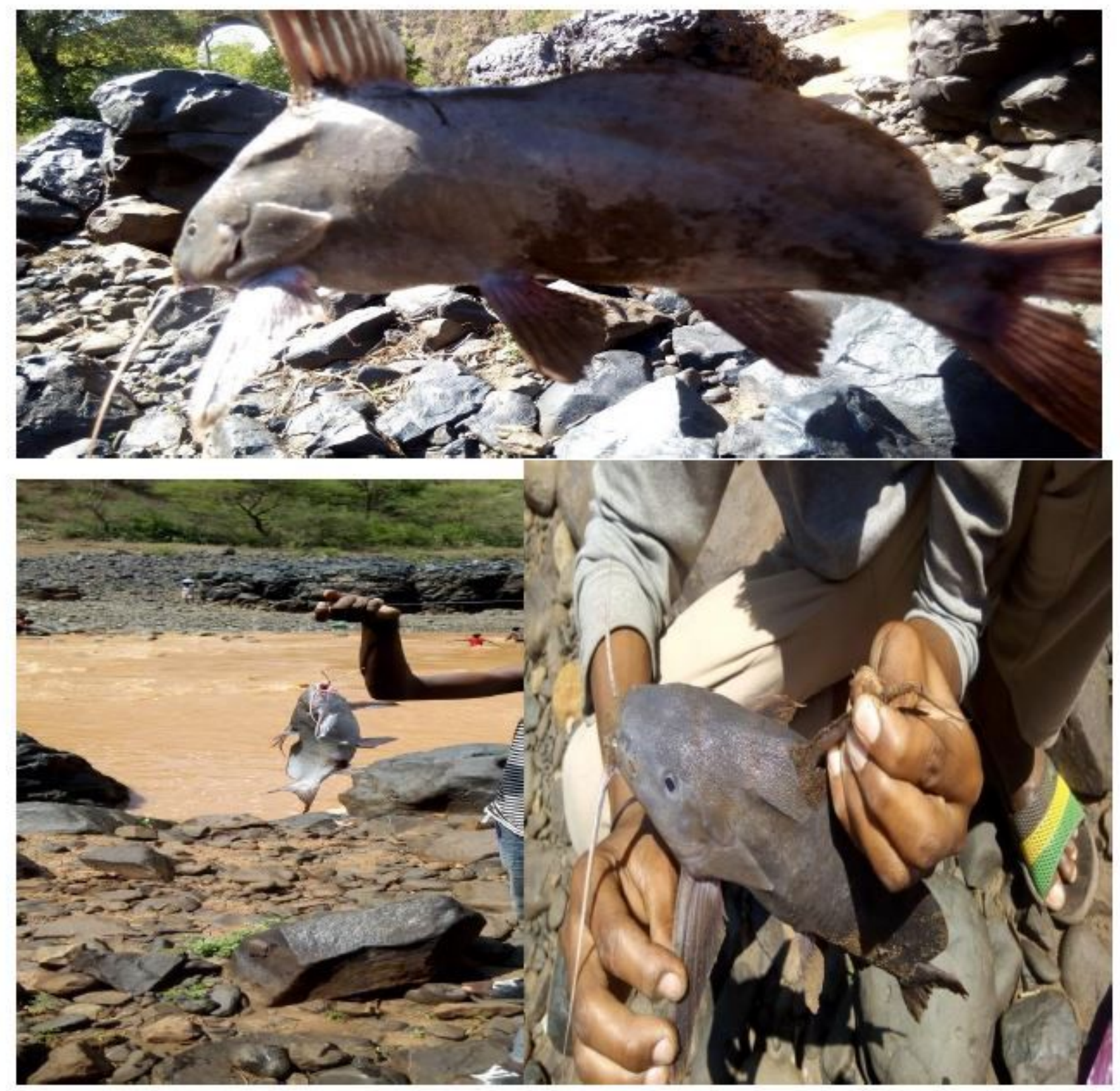

Figure 5

Fishing activity in the study area by using single hook 